\title{
A shift in cloze procedure usage: A new tool for activating ZPD
}

\author{
Parviz Ajideh, Ali Akbar Ansarin, and Sorayya Mozaffarza deh* \\ Department of English Language and Literature, Faculty of Persian Language and Foreign Languages, \\ the University of Tabriz, Tabriz, 29 Bahman Blvd.,Tabriz, Iran, POC: 5166616471
}

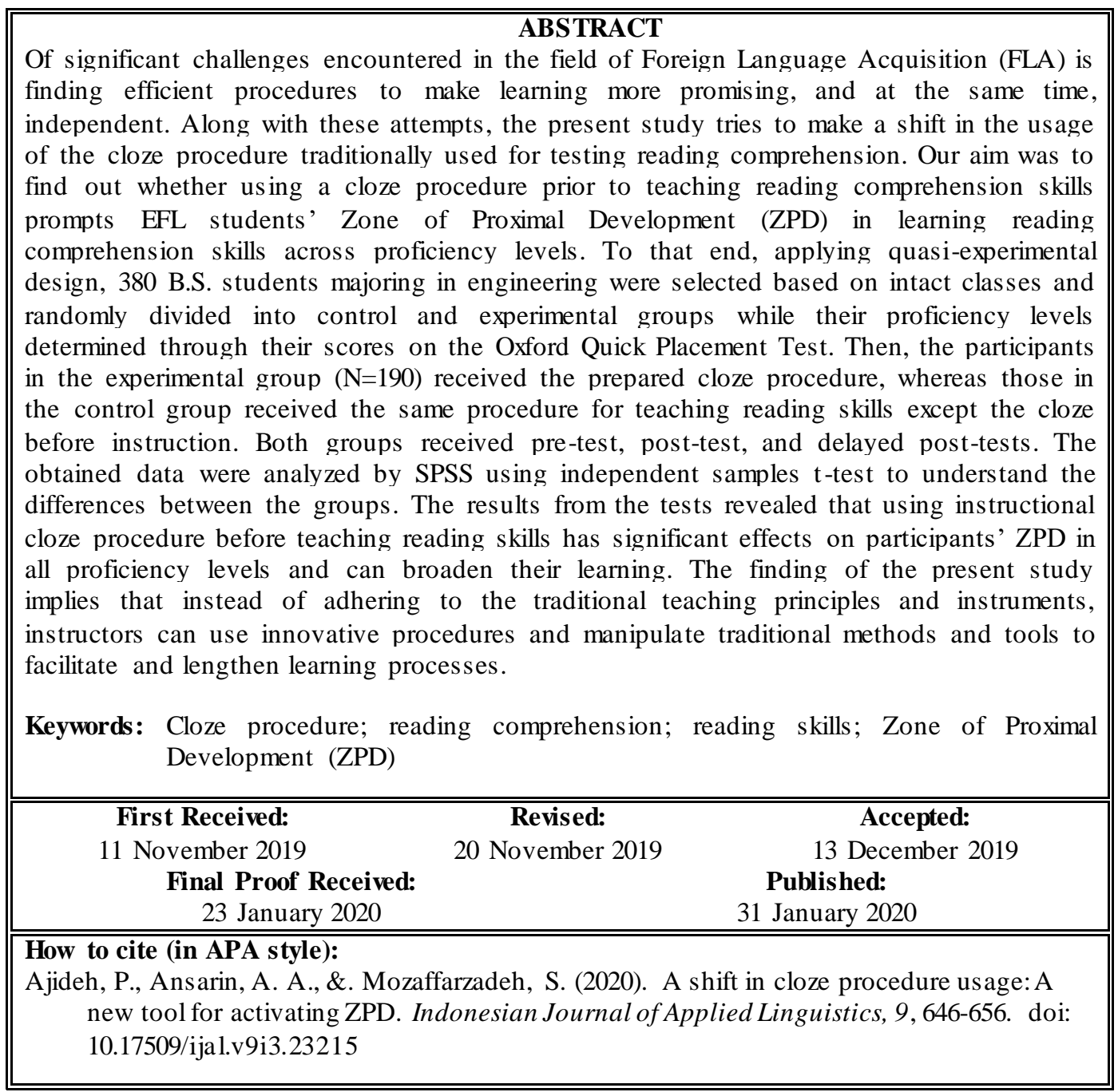

\section{INTRODUCTION}

Globalization and the use of English in science and technology, as well as the language of communications in international contexts, have led to a growing interest in learning English. Consequently, researchers and teachers make enormous attempts to find effective ways to facilitate language learning. Although all four skills are essential in transferring and exchanging information between instructors and students in the classroom, reading receives paramount importance, maybe due to its role at universities and knowledge expanding. Several researchers believe that factors such as schema activating (Zhang, 2016; Ajideh, 2006; Anderson \& Pearson, 1984), features of reading material, reader's characteristics (Hong, 2007), working memories capacity (Unsworth \& McMillan, 2013), individual's learning styles in L2 learning (Ehrman, Leaver, \& Oxford, 2003), morphological awareness (Perfetti \& Stafura, 2014; Levesque, Kieffer, \& Deacon, 2017) and finally the necessity of learning reading skills (Dunning, Johnson, Ehrlinger, \& Kruger, 2003) influence reading comprehension. All of these factors are

\footnotetext{
* Corresponding Author

Email: soraya.mozafarzadeh@yahoo.com
} 
important and should be given considerable attention. Dunning et al. (2003) emphasize that ignoring the issue of being incompetent, learning the necessary skills, cognitive and metacognitive, is of paramount importance. They concluded that the lack of reading skills deprives the readers of obtaining and using cognitive and metacognitive abilities. Considering the importance of reading comprehension skills, Palincsar and Brown (1984, cited in Lewis, 2016) marked that skillful readers continuously try to solve their comprehension problems. In contrast, unskillful readers not only do not take advantage of monitoring strategies but also do not take any action to understand and eliminate their comprehension breakdowns through the conscious use of processing strategies.

As with most academic students in the world, Iranian university students also are in high need of being familiar with reading skills to read texts in English effectively. Given a load of information as well as limitation of time, students need to read and understand texts at a convenient time. In order to overcome this demand, they need to learn reading skills and strategies to be able to read their English textbooks and understand them in appropriate time length. Using traditional methods of teaching reading and reading skills and not obtaining the expected outcomes, the present study sought to find a way to help them by facilitating learning skills and bring about a long-lasting one. Considering the distinctive characteristics of the cloze procedure requiring knowledge of different reading skills to be filled, we decided to examine the cloze procedure, a traditional reading comprehension tool, as an activity before teaching to prompt students' ZPD before starting to teach the skills. We hypothesize that facing with cloze procedure before teaching skills can help them to be aware of their needs. Thus, the aim of our study was to investigate the following question:

1. Is engaging in a cloze procedure prior to teaching effective in activating ZPD for learning reading skills in different proficiency levels?

\section{Zone of Proximal Development}

Vygotsky's Sociocultural Theory grounds on the principle that "human beings are associated with and linked to inside and outside worlds in an indirect fashion." It emphasizes the link between the individual's external and internal worlds through "socio-culturally constructed artifacts" and social interaction leading to the appearance of cultural development (Miri, Alibakhshi, Kushki, \& Bavarsad, 2017, p. 3). Vygotsky (1978) points out that after the social level of development, co-built knowledge, which appears at the inter-psychological level, the internalization occurs by the individual at the intrapsychological horizon. Considering that Vygotsky has not referred to the learning of a particular subject, it can be arguably inferred that this theory of learning can be applied to all kinds of knowledge, including learning a language which basically co-constructed in social interaction either with others or self through private speech. In this regard, Ohta (2000) believes that in order to transform L2 from inter-psychological to intrapsychological functioning, meaningful social interaction is needed.

Vygotsky (1978) sees learners as individuals who need others with more capability to help them to promote their learning within their ZPD. In his definition, ZPD is "the distance between the actual developmental level as determined by independent problem-solving and the level of potential development" (Vygotsky, 1978, p. 86), which can be determined through interaction with more proficient individuals. In the Vygotskian-inspired SCT, interaction with the learner within his/her ZPD is the only way to detect learners' gaps in their interlanguage. This determination of gap and the optimal time to instruct the learners helps the teacher to plan the appropriate agenda to scaffold him/her according to their needs. In addition, it provides the teacher with the possibility of knowing about the already completed maturation process as well as the processes currently maturing or in the state of formation (Aggarwal, 2016). In other words, due to this interaction circumstances, the learners understand their gaps and an internal need to adjust information from different perspectives to reach a united interpretation. So, Vygotsky believes that ZPD, providing us with an efficient tool, offers us the possibility of diagnosing learners' immediate needs and enabling learning.

Moll (2013) considers two factors fundamental to the notion of Zone: 'change' and purposefully establishing new contexts for the occurrence of the change. He points out that the aim of designing the zone in the study was facilitating the analysis of particular outcomes as well as generating mediating processes. However, firstly, we need mechanisms to assess this tool and activate or create it. For assessing ZPD, Aggarwal (2016) suggests 'imitation,' 'collaboration,' and 'instruction.' For creating or activating or 'sharpening' ZPD to provide autonomous learners with the possibility of diagnosing their gaps and facilitating learning, several studies have been done and yet continue (Wass \& Golding, 2014; Soto-Santiago, Rivera, \& Mazak, 2015; Aggarwal, 2016; McCafferty, 2002). In line with these studies, focusing on learner and learning activity, our attempt was to use a cloze procedure for activating learners' $\mathrm{ZPD}$ and define its effectiveness on learning reading comprehension skills by the EFL learners.

\section{Reading comprehension}

Among the four known skills of language, reading is a constituent and complementary component in language learning (Chastain, 1988). In his view, second language learners are in need of skillful readers to not only communicate but also read a large number of authentic materials. He considers comprehending and reconstructing the writer's meaning as the primary 
purpose of the reading. From Vygotskian perspective, reading texts as an activity, bringing wider cultural world among the students in the classroom, should be chosen in a way that fulfills the function of reconstructing intended cultural knowledge of the text as well as associating that knowledge with personal interests and values (Van Oers, 2009). Considering possible challenging nature of such texts to be understood, Rijk, De Mey, De Hann, Van Oers, and Volman (2017) believe that it is teachers' and also pupils' responsibility to supply the learners with reading strategies and scaffolding as promising tools for comprehension.

Lewis (2016) posits that textbook materials tend to be primarily expository in nature, particularly at the tertiary level, with the purpose of informing, describing, explaining, and sometimes persuading the reader. Lewis (2016) believes that learners with poor reading skills often tend to overlook specific outstanding features included within this type of writing, resulting in their task of reading comprehension noticeably challenging while these features of expository texts can enhance readers' concentration and perception of content if they are used properly. Hong (2007), considering the issue from the cognitive aspect, assumes reading as a conversation between a writer and reader. In his opinion, the existence of an interaction between different processes and text features is the essence of broadly known models of fluent reading.

As an efficient approach for improvement of reading comprehension skills, Palinscsar and Brown (1984, cited in Lewis, 2016) designed "reciprocal teaching" whose focus is on developing questioning, clarifying, summarizing, and predicting. They consider them as essential elements of monitoring and fostering reading comprehension proficiencies. Postulating the principles of reciprocal teaching as true, reading comprehension skills can be related to exposure of learners to appropriate reading strategies to raise metacognitively enhanced comprehension. These types of as sociations suggest that an efficient intervention and its successful implementation can be identified with the expectation of helping learners with improving their reading comprehension skills and their general academic performances.

A primary problem being confronted by English learners in EFL contexts is comprehending reading texts, especially academic texts when they experience time limitations. They usually have difficulty in how to improve and use their reading comprehension skills efficiently. In effect, the present study aims to focus on teaching reading skills, of course, by using a cloze procedure as instructional assistance and creator of necessary ZPD in learners to help them learn fast and for a long time.

\section{Cloze procedure}

Cloze procedure is a technique most commonly associated with measuring reading comprehension wherein every $\mathrm{n}^{\text {th }}$ word is removed from a reading passage. The test taker must read the passage and restore the missed words. Mousavi (2009) considers several uses for cloze procedures, such as using a cloze procedure for judging the difficulty of texts, rating bilingual, estimating reading comprehension, studying textual constraints, and evaluating teaching effectiveness. Since its introduction, depending on its target uses, there are three different types of deletion to cloze procedure, including fixed-ration, variable-ratio known as selective or rational, and text-driven method have been introduced. In the fixed-ratio method, every $\mathrm{n}^{\text {th }}$ word is deleted. In the text-driven method, test developers consider the characteristics of the text and make deletion according to the number of discourse structure as well as linguistic structures of the text rather than random deletion without any justification. In rational cloze, the deletion applied based on language function in a particular text. In this type, "linguistic reasoning is used to decide on deletions, and so it is easier to say what each test is intended to measure" (Mousavi, 2009, p. 443). Rational deletion enables the test developer to decide about the deletions and focus on priori-selected items as considered important to a particular target test takers. Also, it is useful in measuring global comprehension ability requiring text level understanding (Yamashita, 2003).

Although the validity of the cloze procedure as an assessment tool of reading comprehension along with its correlation with other reading tests have been studied and mostly accepted (Alderson, 2000; Yamashita, 2003; Sadeghi, 2010, William, Ari, \& Santamaria, 2011), there are still some controversies on its insensitivity to inter-sentential constraints and testing only lower-order skills like grammatical and linguistic knowledge and ignoring discourse-level representations (e.g., Trace, Brown, Janssen, \& Kozhevnikova, 2017; Gellert \& Elbro, 2013; O'Toole \& King, 2010; Green, 2001; Oller \& Jonz, 1994a; \& McKenna \& Layton, 1990). What is essential in the discussion of cloze test validity is its appropriate design and use. Green (2001) considers the cloze test as a valid assessment of a reader's ability to theoretical text integration when it is designed and used appropriately.

Contrary to its introduction and use as an assessment tool for reading comprehension (Mariotti \& Homan, 2005; Schumm, 2006; Lapp, Fisher, \& Wolsey, 2009), cloze procedure has also been applied and explored as an instructional tool (Barnitz, 1988; Jacobson, 1990 cited in (Mozaffarzadeh, 2019); Blachowicz \& Ogle, 2008). Blachowicz and Ogle (2008) consider the cloze procedure as an instructional tool and argue that it is a remarkably promising strategy in individualized contexts. They believe that the cloze procedure requires the students to make meaning through activating a network between linguistic and cognitive processes. These authors define reading comprehension as a dynamic process of connecting ideas across words, sentences, and paragraphs, while the reader reads and monitor his/her process of meaningmaking and interpreting. In other words, they stress that 
establishing meaningful connections across various parts of a text is one of the main characteristics of reading comprehension, a process that entails the students' ability to go back and forth between sentences, paragraphs, and the whole of the text. Barnitz (1988) emphasizes the significant role of cloze in the instruction of comprehension and points out that the cloze procedure has been generated as a way of promoting comprehension. Therefore, it can be said that cloze activities do not teach by themselves, but they can be used in the comprehension strategy instruction.

\section{METHOD}

\section{Design}

The aim of this study is to examine whether engaging in a cloze procedure before teaching is effective in activating ZPD for learning reading skills in different proficiency levels. The research methodology and data collection procedure adopted in the present study was a quasi-experimental method, including pretest, posttest, and delayed posttest. Regarding the data analysis, we used Cronbach's alpha for testing the reliability of the tests. Also, descriptive statistics were performed to have the mean scores and standard deviation of the groups. To have a detailed analysis and significance of the differences, an independent t-test was run using SPSS.

\section{Participants}

The context of the present study was two state universities in Iran, the University of Tabriz and Sahand University of Technology. The participants of the study were 380 freshmen, both male $(n=203)$ and female $(n=177)$, majoring in engineering selected based on six intact classes. The age of participants ranged from 18 to 22, and their mother languages were Farsi, Azeri, and Kurdish. They were randomly assigned to control (190) and experimental (190) groups. All the participants had the experience of learning English in high school and some in private language institutes. They were taking a general English course at the university, one of the compulsory subjects, credited three (three hours in a week) and took 17 weeks.

According to the categorization manual of the placement test, we had five proficiency levels, including basic, breakthrough, elementary, intermediate, and advanced. However, in experimental and control groups, we had only 3-6 breakthrough and advanced participants that could not make an independent proficiency group statistically. Consequently, we excluded the data obtained from these participants in the data analysis stage, although they took part in all stages. Therefore, we had three proficiency levels in each group.

The data collection in this study was conducted during normal university class sessions. The participants need to learn to read texts in English to be familiar with the new advances in their own fields; however, they usually lack the required reading skills to be a strategic reader after passing the General English Course. As experienced by reading instructors every semester, we observed our students struggling with the problem of reading texts in English due to the lack of skills. Therefore, we were trying to find effective ways to instruct frequently needed reading skills. Since we were aware of the beneficial characteristics of the cloze procedure, we decided to examine its effect before instructing reading skills to create or promote the required $\mathrm{ZPD}$ in our participants.

\section{Materials and instruments Oxford Quick Placement Test (version 2)}

In order to reach a relative homogeneity and eliminate the effects of language proficiency of participants on their performance and assessment, a placement test was administered prior to the study. Oxford Quick Placement Test (OQPT) was used to identify the participants' language proficiency level to be able to provide reading texts and cloze texts according to their proficiency levels. It includes 60 multiple-choice items with two parts to be completed with 30-45 minutes. According to the manual of the OQPT, the participants can be categorized as a basic, breakthrough, elementary, intermediate, and advanced groups.

\section{Reading comprehension text}

Eighteen reading comprehension texts, each approximately 500-700 words, were used as a pre-test, post-test, and delayed post-test in three proficiency levels (three levels in two groups with three tests). Besides considering the proficiency levels of the texts, we purposefully selected those texts, which were inherently designed by the book-authors to teach a particular reading skill. For example, the first text of unit three and its following questions in Inside Reading One are designed for teaching scanning. To deal with the issue of authenticity and readability of the texts, the used texts in this study were taken from Inside Academic Reading Series published by Oxford for academic reading purposes for different proficiency levels are used by most of the EFL teachers in Iran for general English courses. The questions and their answers related to each skill also were taken from these books to assure the issue of reliability and validity.

\section{Cloze texts}

In the present study, we used the other nine texts with the above-mentioned conditions to prepare cloze texts (because they were not used with the purpose of testing reading comprehension, but as a reading activity, we decided to name them cloze texts) as a pre-teaching activity before teaching reading skills. The cloze texts were prepared for each of the three skills separately in three proficiency levels to be used in the experimental group. These texts were prepared from the main texts that we aimed to teach a skill in that session. The deletion of the words was based on rational deletion because it enables the test developer to decide about the 
type of deletions and focus on priori-selected items as considered important to a particular target test takers.

Regarding the skill that we aimed to teach, we decided on the deleted items. For example, for the clozes prepared for the previewing skill, we kept the keywords, proper nouns, and dates. We tried not to delete the items that help the participants to recognize the specific information helping to answer the related questions. If $\mathrm{n}^{\text {th }}$ deletion rule of the cloze tests was followed, most of the information needed to answer the questions related to skills would have been deleted, and it would have made the procedure of understanding and assessment more complex because the participants needed to cope with the skill of answering cloze test, not the skills required for reading comprehension. The prepared cloze texts were just for development and making participants curious about the ways to reach answers to the accompanying questions, and they were not expected to fill in the blanks in the texts. They were only assessed by answering the accompanying questions.

\section{Procedure}

This study was initiated by administrating the OQPT placement test to assess participants' language proficiency levels. The overall research took three five-weeks. In the first five-week, we worked on previewing skills. The second five-week was allocated to scanning skill. Finally, in the third five-week, we started skimming skills. The taken steps were repeated for all three skills. Of course, we instructed our other usual subjects in these sessions, and the study was related only to reading time.

The first step, in each five-week, was determining relative homogeneity and setting a basis for comparis on of the scores through administering a pre-test before instructing each skill. In the second step, we gave three prepared cloze texts for previewing skills to the participants in the experimental group according to their proficiency level. They had three mins to scan the text and questions. Then they had five mins to check their answers and enter them to the answer sheet. The objective of these stages was to make them aware of their previous knowledge and gaps. Mozaffarzadeh (2019) found that when her learners faced with the problems that they did not know how to solve them, they were more focused on what they need to learn in the instruction time. Her learners stated in the interview that when they were aware of their insufficiencies, they plan to be more focused, whereby they learn better. The use of cloze texts was limited only to the first weeks and before instruction because we wanted to see its effectiveness before teaching skills.

The fourth step was the instruction phase being the same for both groups. We did not allocate any time limitations for the instruction period. The previewing skill was instructed explicitly, and it is explained how the participants can apply the skill to reach answers. The instructor tried to clarify any problems that the participants faced. In the fifth step, the experimental group was asked to come back to the cloze texts to check their answers and evaluate their learning, and if needed, correct their wrongly answered questions. At the same stage, the control group moved to the main text to apply the instructed skill on the reading and assess their learning. This stage ended with helping participants to solve their potential problems on the previewing skill. After 10 minutes break with the aim of refreshing, we administered the posttest to both groups to have the effect of cloze texts. In weeks 2, 3, and 4, the participants practiced the previewing skill on different texts, which sometimes were above their proficiency levels. The used materials, in the practice stage, were the same for both groups. In the fifth week, we administer the delayed posttest to see the long-term effect of using the cloze procedure before instruction.

The mentioned steps for previewing skills were repeated for scanning and skimming in the following weeks. In the first weeks of the five-week treatment, we only instructed one reading skill. As it is seen, everything was mostly the same for both groups except the cloze procedure, which was received by the experimental group before instruction. The details of the procedure can be seen in Table 1 .

\section{RESULTS}

The section includes the data related to the pre-test, post-test, and delayed post-test applied through three stages for the control and experimental groups, each with 190 participants in three proficiency levels for three reading skills, preview, scanning, and skimming. The comparisons were carried out between two groups considering the participants' English proficiency level. The data were gathered through applying the cloze procedure before and after teaching to the experimental group and analyzed using descriptive and inferential statistics and Cronbach's alpha for testing the reliability $(r=0.85)$, dependent and independent $t$-test, analys is of variance and covariance for the covariate variable (pretest).

As reported in Table 2, the mean score obtained from the preview pre-test is 23.74 , in the post-test is 57.86 , and in delayed post-test is 66.45 . The obtained mean score in the scanning pre-test is 32.38 , in the posttest is 63.81 , and in delayed post-test is 71.88 , while the values were $17.84,52.41$, and 61.34 , respectively, for the scanning. Comparing the mean scores of post-test and delayed post-test to pre-test for all three skills, preview, scanning, and skimming, shows that in overall, the differences in mean scores are considerably increased. However, to capture the effect of the treatment, the scores of the experimental group, as well as the control group, had to be compared in the three administrations, i.e., pretest, posttest, and delayed posttest. Table 3 reports the descriptive statistics of the scores obtained by two groups in these administrations. 
Table 1. Steps of carrying out this study

\begin{tabular}{|c|c|c|c|c|c|}
\hline Week & Activities & Aim & Time & $\begin{array}{l}\text { Control } \\
\text { group }\end{array}$ & $\begin{array}{l}\text { Experimental } \\
\text { group }\end{array}$ \\
\hline $\begin{array}{l}\text { Prior to the } \\
\text { study } \\
\text { Week } 1\end{array}$ & Administering OQPT & $\begin{array}{l}\text { Determining participants } \\
\text { proficiency level }\end{array}$ & $60 \mathrm{mins}$ & yes & yes \\
\hline Step 1 & Administering pretest & $\begin{array}{l}\text { Determining homogeneity of } \\
\text { groups }\end{array}$ & 10 mins & yes & yes \\
\hline Step 2 & $\begin{array}{l}\text { Giving cloze texts to do targeted } \\
\text { skill activity }\end{array}$ & $\begin{array}{l}\text { As an instrument for } \\
\text { activating ZPD }\end{array}$ & 3 mins & no & yes \\
\hline Step 3 & $\begin{array}{l}\text { Asking participants to answer the } \\
\text { following questions }\end{array}$ & $\begin{array}{l}\text { To make participants aware of } \\
\text { their gaps }\end{array}$ & $5 \mathrm{mins}$ & no & yes \\
\hline Step 4 & Instructing the skill by teacher & & $\begin{array}{r}\text { Without } \\
\text { time } \\
\text { limitation }\end{array}$ & yes & yes \\
\hline \multirow[t]{2}{*}{ Step 5} & $\begin{array}{l}\text { Asking participants in the } \\
\text { experimental group to re-check their } \\
\text { cloze texts and answers, then move } \\
\text { to the main text. }\end{array}$ & $\begin{array}{l}\text { Self-assessing their own } \\
\text { answers }\end{array}$ & 10 mins & no & yes \\
\hline & $\begin{array}{l}\text { Asking participants in the control } \\
\text { group to move to the main text and } \\
\text { apply the instructed skill. }\end{array}$ & $\begin{array}{l}\text { Practicing and assessing their } \\
\text { learning }\end{array}$ & 10 mins & yes & yes \\
\hline Step 6 & Administering posttest & $\begin{array}{l}\mathbf{1 0} \text { mins break } \\
\text { To determine the effect of } \\
\text { cloze texts }\end{array}$ & 5 mins & yes & yes \\
\hline Weeks 2, 3, 4 & Practicing the skill of different texts & $\begin{array}{l}\text { To provide the participants } \\
\text { with the possibility of } \\
\text { mastering skills }\end{array}$ & & yes & yes \\
\hline Week 5 & Administering delayed posttest & $\begin{array}{l}\text { To determine the long term } \\
\text { effect of using cloze texts }\end{array}$ & $5 \mathrm{mins}$ & yes & yes \\
\hline
\end{tabular}

Table 2. Descriptive statistics of the overall scores in reading skills

\begin{tabular}{|c|c|c|c|c|c|c|}
\hline & & $\mathbf{N}$ & Minimum & Maximum & Mean & Std. Deviation \\
\hline \multirow[t]{3}{*}{ Preview } & Pre-test & 380 & .00 & 70.00 & 23.7434 & 14.02143 \\
\hline & Posttest & 380 & 12.50 & 100.00 & 57.8653 & 15.99013 \\
\hline & Delayed posttest & 380 & 20.00 & 100.00 & 66.4592 & 17.27751 \\
\hline \multirow[t]{3}{*}{ Scanning } & Pretest & 380 & .00 & 70.00 & 32.3829 & 14.40312 \\
\hline & Posttest & 380 & 25.00 & 97.50 & 63.8184 & 14.20366 \\
\hline & Delayed posttest & 380 & 30.00 & 100.00 & 71.8895 & 13.98193 \\
\hline \multirow[t]{3}{*}{ Skimming } & Pretest & 380 & .00 & 55.00 & 17.8461 & 13.33506 \\
\hline & Posttest & 380 & 25.00 & 95.00 & 52.4118 & 15.41662 \\
\hline & Delayed posttest & 380 & 27.50 & 100.00 & 61.3447 & 16.30367 \\
\hline
\end{tabular}

At the beginning of the study, to check up the lack of significant differences between the experimental and control groups, an independent sample t-test was run for each skill. The result obtained from the independent samples t-tests, Table 4, for each skill indicates a lack of significant difference between the mean scores of groups $(\mathrm{t}$ preview $=-.0104, \mathrm{p}=0.917>0.05 ; \mathrm{t}$ scanning $=$ $.0 .756, \mathrm{p}=0.45>0.05 ; \mathrm{t}$ skimming $=-0.052, \mathrm{p}=0.959>$ 0.05). Therefore, the control and experimental groups did not differ regarding preview, scanning, and skimming skills statistically before the intervention and could be logically compared at the next stages of the study. It should be mentioned that the effects of participants' proficiency levels have been controlled in all stages.
To compare the mean scores of experimental and control groups' post-test scores on each of the three skills, three independent samples t-tests were run (Table 5). After the intervention, the mean of preview score for the control group $(M=54.64)$ is smaller than that of the experimental group $(\mathrm{M}=61.08)$, and the result of independent t-test (Table 4) revealed that two groups differed significantly $(\mathrm{t}=-4.00, \mathrm{p}=0.000<0.05)$ after using cloze procedure. Moreover, the mean score for the control group in the scanning posttest $(M=61.15)$ is larger than that of the experimental group $(M=66.47)$, and the result of the independent t-test revealed that the two groups differed significantly $(\mathrm{t}=-3.71, \mathrm{p}=0.000<$ $0.05)$ after using cloze procedure. Finally, the mean score for the control group $(\mathrm{M}=49.28)$ in the skimming 
posttest is smaller than that of the experimental group $(\mathrm{M}=55.53)$. The result of the independent $t$-test revealed that the two groups differed significantly $(\mathrm{t}=-4.03, \mathrm{p}$ $=0.000<0.05)$ after using the cloze procedure.

Table 3. Descriptive statistics of the scores obtained by two groups

\begin{tabular}{|c|c|c|c|c|c|c|}
\hline & & & $\mathbf{N}$ & Mean & SD & Std. Error of Mean \\
\hline \multirow[t]{6}{*}{ Preview } & \multirow[t]{2}{*}{ Pre-test } & Control & 190 & 23.6684 & 12.95027 & .93951 \\
\hline & & Experimental & 190 & 23.8184 & 15.05060 & 1.09188 \\
\hline & \multirow[t]{2}{*}{ Posttest } & Control & 190 & 59.7763 & 13.32524 & 96671 \\
\hline & & Experimental & 190 & 73.1421 & 18.20019 & 1.32038 \\
\hline & \multirow[t]{2}{*}{ Delayed posttest } & Control & 190 & 59.7763 & 13.32524 & .96671 \\
\hline & & Experimental & 190 & 73.1421 & 18.20019 & 1.32038 \\
\hline \multirow[t]{6}{*}{ Scanning } & \multirow[t]{2}{*}{ Pretest } & Control & 190 & 31.8237 & 13.63350 & .98908 \\
\hline & & Experimental & 190 & 32.9421 & 15.14915 & 1.09903 \\
\hline & \multirow[t]{2}{*}{ Posttest } & Control & 190 & 61.1579 & 13.08737 & .94946 \\
\hline & & Experimental & 190 & 66.4789 & 14.80015 & 1.07372 \\
\hline & \multirow[t]{2}{*}{ Delayed posttest } & Control & 190 & 66.8947 & 12.72613 & .92325 \\
\hline & & Experimental & 190 & 76.8842 & 13.41305 & .97308 \\
\hline \multirow[t]{6}{*}{ Skimming } & \multirow[t]{2}{*}{ Pretest } & Control & 190 & 17.8105 & 11.88307 & .86209 \\
\hline & & Experimental & 190 & 17.8816 & 14.67579 & 1.06469 \\
\hline & \multirow[t]{2}{*}{ Posttest } & Control & 190 & 49.2842 & 13.45906 & .97642 \\
\hline & & Experimental & 190 & 55.5395 & 16.60687 & 1.20479 \\
\hline & \multirow[t]{2}{*}{ Delayed posttest } & Control & 190 & 53.8974 & 14.26261 & 1.03472 \\
\hline & & Experimental & 190 & 68.7921 & 14.76788 & 1.07137 \\
\hline
\end{tabular}

Table 4. Independent samples t-test: Checking initial homogeneity

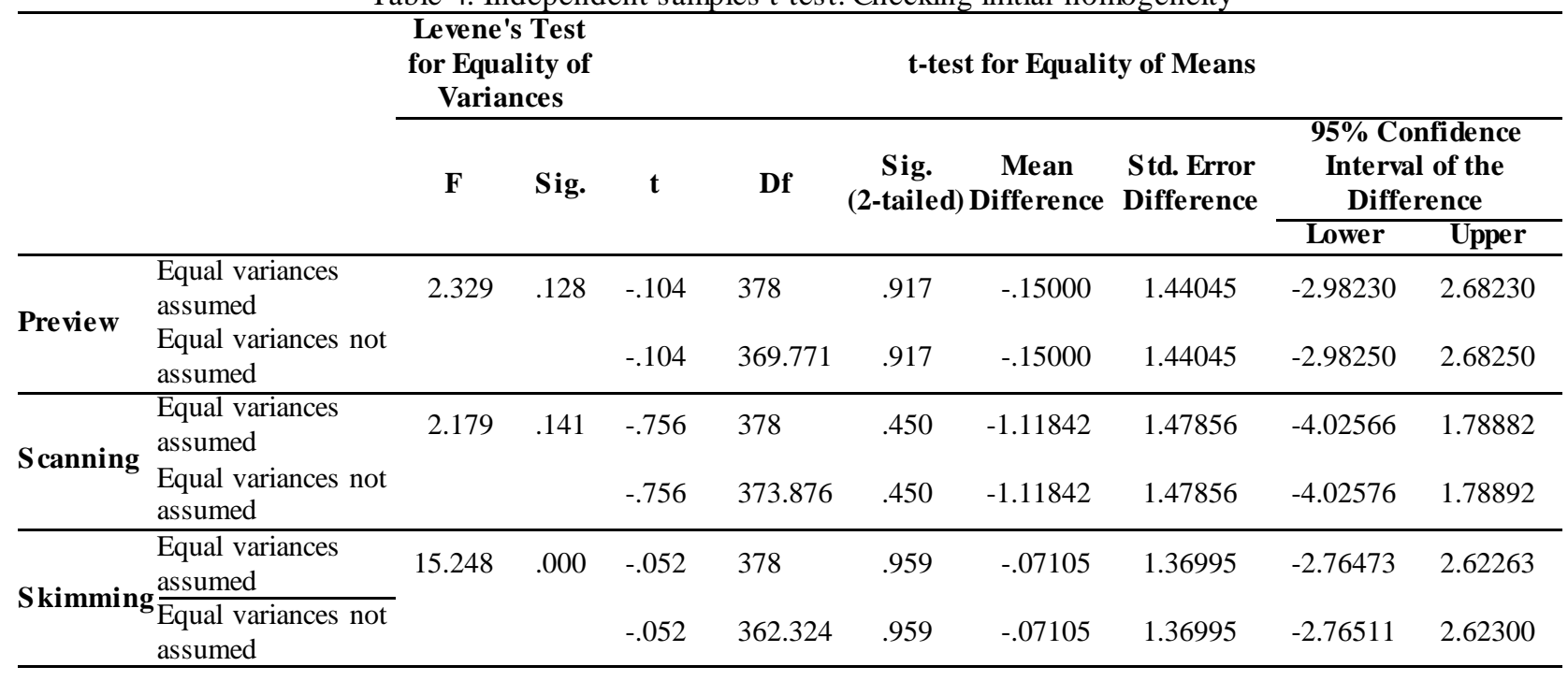

Next, the two groups were compared based on their performances on the delayed posttest using three sets of independent samples t-tests. Table 3, above, shows a mean score of 59.77 for the control group in delayed post-test of review, and for the experimental, it is 73.14. Also, the independent t-test result (Table 6) revealed the two groups differed significantly $(\mathrm{t}=8.168$, $\mathrm{p}=0.000<0.05)$ five weeks after using cloze procedure. Moreover, the mean score for the control group in the scanning delayed posttest $(M=66.89)$ is larger than that of the experimental group $(M=76.88)$, and the result of the independent t-test revealed that the two groups differed significantly $(\mathrm{t}=-744, \mathrm{p}=0.000<$ $0.05)$ after the treatment. Finally, the mean score for the control group in delayed post-test of skimming is 53.89, and for the experimental, it is 68.79 . The result obtained from the independent sample t-test revealed that the two groups differed significantly $(\mathrm{t}=-10, \mathrm{p}=0.001<0.05)$ five weeks after using the cloze procedure. 
Table 5. Independent samples t-tests for post-test scores

\begin{tabular}{|c|c|c|c|c|c|c|c|c|c|c|}
\hline & & \multicolumn{2}{|c|}{$\begin{array}{c}\text { Levene's Test for } \\
\text { Equality of } \\
\text { Variances } \\
\end{array}$} & \multicolumn{7}{|c|}{ t-test for Equality of Means } \\
\hline & & \multirow[t]{2}{*}{$\mathbf{F}$} & \multirow[t]{2}{*}{ Sig. } & \multirow[t]{2}{*}{$\mathbf{T}$} & \multirow[t]{2}{*}{ df } & \multirow[t]{2}{*}{$\underset{\text { (2-tailed) }}{\text { Sig. }}$} & \multirow[t]{2}{*}{$\begin{array}{c}\text { Mean } \\
\text { Difference }\end{array}$} & \multirow[t]{2}{*}{$\begin{array}{l}\text { Std. Error } \\
\text { Difference }\end{array}$} & \multicolumn{2}{|c|}{$\begin{array}{l}\text { 95\% Confidence } \\
\text { Interval of the } \\
\text { Difference } \\
\end{array}$} \\
\hline & & & & & & & & & Lower & Upper \\
\hline \multirow[t]{2}{*}{ Preview } & $\begin{array}{l}\text { Equal variances } \\
\text { assumed }\end{array}$ & 14.513 & .000 & -4.000 & 378 & .000 & -6.43684 & 1.60901 & -9.60058 & -3.27311 \\
\hline & $\begin{array}{l}\text { Equal variances not } \\
\text { assumed }\end{array}$ & & & -4.000 & 354.432 & .000 & -6.43684 & 1.60901 & -9.60125 & -3.27243 \\
\hline \multirow[t]{2}{*}{ S canning } & $\begin{array}{l}\text { Equal variances } \\
\text { assumed }\end{array}$ & .794 & .373 & -3.712 & 378 & .000 & -5.32105 & 1.43330 & -8.13928 & -2.50282 \\
\hline & $\begin{array}{l}\text { Equal variances not } \\
\text { assumed }\end{array}$ & & & -3.712 & 372.423 & .000 & -5.32105 & 1.43330 & -8.13942 & -2.50269 \\
\hline \multirow{2}{*}{\multicolumn{2}{|c|}{$\begin{array}{l}\text { SkimmingEqual variances } \\
\text { assumed } \\
\text { Equal variances not } \\
\text { assumed }\end{array}$}} & 11.971 & .001 & -4.034 & 378 & .000 & -6.25526 & 1.55078 & -9.30450 & -3.20603 \\
\hline & & & & -4.034 & 362.451 & .000 & -6.25526 & 1.55078 & -9.30492 & -3.20561 \\
\hline
\end{tabular}

Table 6. Independent samples t-tests for delayed post-test scores

\section{Levene's Test for}

Equality of t-test for Equality of Means

Variances

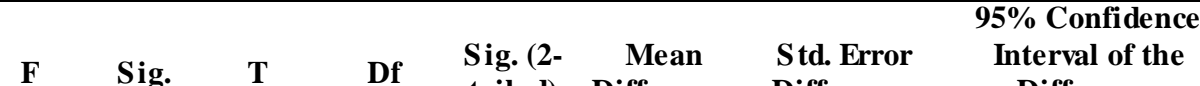

F Sig. T T tailed) Difference Difference Difference

\begin{tabular}{|c|c|c|c|c|c|c|c|c|c|c|}
\hline \multirow{3}{*}{ Preview } & \multirow{3}{*}{$\begin{array}{l}\text { Equal variances } \\
\text { assumed } \\
\text { Equal variances } \\
\text { not assumed }\end{array}$} & \multirow{3}{*}{18.239} & \multirow{3}{*}{.000} & \multirow[b]{2}{*}{-8.168} & \multirow[b]{2}{*}{378} & \multirow[b]{2}{*}{.000} & \multirow[b]{2}{*}{-13.36579} & \multirow[b]{2}{*}{1.63644} & \multirow{2}{*}{$\begin{array}{c}\text { Lower } \\
-16.58346\end{array}$} & \multirow{2}{*}{$\begin{array}{c}\text { Upper } \\
-10.14812\end{array}$} \\
\hline & & & & & & & & & & \\
\hline & & & & -8.168 & 346.397 & .000 & -13.36579 & 1.63644 & -16.58440 & -10.14718 \\
\hline \multirow[t]{2}{*}{ Scanning } & $\begin{array}{l}\text { Equal variances } \\
\text { assumed }\end{array}$ & .049 & .825 & -7.447 & 378 & .000 & -9.98947 & 1.34137 & -12.62696 & -7.35198 \\
\hline & $\begin{array}{l}\text { Equal variances } \\
\text { not assumed }\end{array}$ & & & -7.447 & 376.960 & .000 & -9.98947 & 1.34137 & -12.62699 & -7.35196 \\
\hline \multirow[t]{2}{*}{ Skimmin } & $\begin{array}{l}\text { gEqual variances } \\
\text { assumed }\end{array}$ & .229 & .633 & -10.000 & 378 & .001 & -14.89474 & 1.48946 & -17.82340 & -11.96608 \\
\hline & $\begin{array}{l}\text { Equal variances } \\
\text { not assumed }\end{array}$ & & & -10.000 & 377.543 & .001 & -14.89474 & 1.48946 & -17.82341 & -11.96606 \\
\hline
\end{tabular}

\section{DISCUSSION}

In this study, we aimed to investigate the effectiveness of the cloze procedure to activate Iranian engineering students' ZPD before teaching reading comprehension skills. Below we will discuss the characteristics of using such tools for activating learners' ZPD. Also, it will be argued how using prereading activities to assist learners in learning skills better and using them in their real-life environment rather than using the usual way of instructing reading comprehension, which mostly leads to rote memorization.

Smagorinsky (2011) views reading as an activity in which the reader inscribe him/herself in a text to be enabled to access the content. This engagement in the content of a text to generate meaning involves complex cognitive and metacognitive processes. Grab and Stoller (2013) argues that strategic readers use these processes automatically. Therefore, learning reading skills seems indispensable to every reader. By following specific stages, we tried to instruct our students to help them learn these skills easier and practice them to internalize and automatize them. As Grab and Stoller (2013) point out, teachers can promote strategic reading and encourage students by asking them to decide on what they know and what they want to know. This happens through using prereading activities like asking the students to answer some questions before teaching. It can be said it is similar to Vygotsky's notion of using artificial instruments for creating ZPD (Vygotsky, 1978). In other words, when the learners become aware of what they know through activation of their background knowledge and what they need to know, they start to set their goal, plan and monitor as well as evaluate their learning. 
In this study, we tried to choose those texts that are meaningful and appropriate for the participants' proficiency levels. During the study, the instructors (researchers themselves) made an attempt to seize opportunities to instruct and support when the participants were in need of a strategy for a better understanding of the texts. To have an efficient instruction, we followed specific stages to help the participants to understand 'what' as well as 'how' and 'when' to use the skills that they are learning. We aimed to channel the participants to be strategic and autonomous in reading comprehension, even in the texts are beyond their reading capability. In this study, we tried conversations in both groups to understand their problems and needs and provide the necessary strategies and skills to guide them through the passage of becoming autonomous, a dynamic switch between instruction and support (Rijk et al. 2017), which is the core of the concept of ZPD.

Cloze procedure's potentiality to prompt metacognitive awareness, i.e., 'think about thinking,' is perhaps one of the most convincing arguments to use them as fostering reading comprehension activity (Burley, Brown, \& Suanders, 1985). As Blachowicz and Ogle (2008) argue, the cloze procedure with its specific characteristics requires making a connection between reading components and cognitive processes to make meaning of the text. To be a successful meaningmaker, the reader needs to be a strategic reader. Regarding this feature, we chose cloze texts as our tool. The findings of the study supported the hypothesis that engaging in a cloze procedure before the instruction is effective in activating ZPD for learning reading skills in different proficiency levels. The findings are valid for all three proficiency levels we had in this study. A greater improvement has been observed in the mean scores of the basic, elementary, and intermediate participants in the experimental group compared to those of the control group. Our finding also supports the study by Mozaffarzadeh (2019), which considers the is sue from the participants' point of view. In her study, she found out that participants' learning of reading skills facilitated by using the cloze procedure as a pre-reading activity. Her participants pointed out that using a cloze procedure helped them to understand what they know and what they lack about that specific skill, so their minds were ready to learn new things they need to fill in their gaps during the instruction. Similarly, the mean scores of our participants in the experimental group in the posttest and delayed posttest showed more growth than those of the participants in the control group.

Vygotsky (1978) emphasizes the importance of work inside ZPD and states the "creation and use of artificial stimuli which become the immediate causes of behavior" (p. 39). In this study, following Vygotsky's argument, creating a potential learning site or the required ZPD for learning reading skills in teacherfronted classes was meant. Wells (1999, cited in Khosravi, 2017) defines it as an "enlarged notion of ZPD" and writes "a site of potential learning that is created when participants of all ages ... collaborate in understanding a concept or solving a problem" (pp. 7980). Our findings lend credence to the findings of Mirzaei and Eslami (2013), Soto-Santiago et al. (2015), and Rijk et al. (2017), who founded out that ZPDactivated instruction can facilitate learner's learning in different aspects of learning a language.

To conclude, this study found a significant effect for the use of cloze procedure as a tool for stimulating participants' ZPD before instructing reading skills like previewing, scanning and skimming in all three levels of proficiency. The results of this study implied that instructors should not stick to traditional methods of teaching even when they teach in teacher-fronted classes and be creative by doing action research during their instruction and find creative ways to help their learners. This research itself was the result of the writers' observations during teaching reading comprehension in EFL context and their attempts to innovate new processes to effective teaching of reading skills although due to crowded classed we could not do case studies or observations to consider the participants' behavior of learning in more detail. One of our suggestions for the future studies is doing a qualitative, maybe 'think aloud' work, to look at the learners' mind to see what happens when they face with a text with questions at the end which they don't know how to answer them and its effect on their future learning.

As with all research in applied linguistics, there are inevitable limitations. The first significant limitation, in the present study, was crowded classes with students in different proficiency levels. This inhomogeneity took lots of time to prepare materials that are suitable for all students, and sometimes they were not. The second limitation relates to the allocated time for the course during the semester, three hours a week. We should move forward according to the lesson plan of the universities and do our research.

\section{REFERENCES}

Aggarwal, C. (2016). Recommender system: The textbook. Switzerland: Springer International Publishing.

Ajideh, P. (2006). Schema-theory based considerations on pre-reading activities. The Asian EFL Journal, 16(2), 1-19.

Alderson, J. C. (2000). Assessing reading. Cambridge: Cambridge University Press.

Anderson, R. C., \& Pearson, P. D. (1984). A schematheoretic view of basic processes in reading comprehension. In P. D. Pearson (Ed.), Handbook of reading research (pp. 255-291). New York: Longman.

Barnitz, J. C. (1988). Revising grammar instruction for authentic composing and comprehending. The Reading Teacher, 51(7), 608-611.

Blachowicz, C. \& Ogle, O. (2008). Reading comprehension: Strategies for independent learners. New York: Guilford Press. 
Burley, J., Brown, B. G., \& Suanders, B. L. (1985, May). Metacognition: Theory and application for college readers. Paper presented at The Annual Meeting of the International Reading Association 30th, New Orleans, LA.

Burgmeier, Arline. (2012) Inside reading: The academic word list in context $\left(2^{\text {nd }}\right.$ edn.). New York: Oxford University Press

Chastain, K. (1988). Developing second language skills: Theory and practice (3rd Brace Jovanovich.edn.). San Diego CA: Harcourt.

Dunning, D., Johnson, K., Ehrlinger, J., \& Kruger, J. (2003). Why people fail to recognize their own incompetence. Current Directions in Psychological Science, 12(3), 83-87. doi: 10.1111/1467-8721.01235

Ehrman, M., Leaver, B. L., \& Oxford, R. (2003). A brief overview of individual differences in second language learning. System, 31(3), 313-330. doi: 10.1016/S0346-251X(03)00045-9

Gellert, A. S., \& Elbro, C. (2013). Cloze tests may be quick, but are they dirty? Development and preliminary validation of a cloze test of reading comprehension. Journal of Psychoeducational Assessment, 31(1), 16-28. doi: $10.1177 / 0734282912451971$

Grab, W., \& Stoller, F. L. (2013). Teaching and researching reading (2nd edn.). NY: New York: Routledge.

Green, B. B. (2001). Testing reading comprehension of theoretical discourse with cloze. Journal of Research in Reading, 24(1), 82-98. doi: 10.1111/1467-9817.00134

Hong, C. Z. (2007). The effect of learning strategies on reading comprehension. Sino-US English Teaching, 4(4), 15-18.

Khosravi, S. K. (2017). Symmetrical and asymmetrical scaffolding in English reading comprehension of Iranian EFL Learners. Europian Journal of English Language Teaching, 2(1), 165-175. doi: 10.5281/zenodo.400739

Lapp, D., Fisher, D., \& Wolsey, T. D. (2009). Literacy growth for every child: Differentiated small group instruction K-6. New York, NY: Guilford Press.

Levesque, K., Kieffer, M. J., \& Deacon, H. (2017). Morphological awareness and reading comprehension: Examining mediating factors. Journal of Experimental Child Psychology, 160(1), 1-20. doi: 10.1016/j.jecp.2017.02.015

Lewis, R. E. (2016). Reciprocal teaching as a reading comprehension strategy among first-year industrial technology teacher-education majors (Unpublished doctoral dissertation). University of Technology, Jamaica.

Mariotti, A. S. \& Homan, S. P. (2005). Linking assessment to instruction (4th edition). Mahwah, NJ: Lawrence Erlbaum Associates

McCafferty, S. G. (2002). Gesture and creating zones of proximal development for second language learning. The Modern Language Journal, 86(2), 192-203. doi: 10.1111/1540-4781.00144

McKenna, M. C., \& Layton, K. (1990). Concurrent validity of cloze as a measure of intersentential comprehension. Journal of Educational Psychology, 82(2), 372-377. doi: 10.1037/00220663.82.2.372

Miri, M., Alibakhshi, G., Kushki, A., \& Bavarsad, P. S. (2017). Going beyond one-to-one mediation in the zone of proximal development (ZPD): Concurrent and proximal group dynamic assessment. Eurasian Journal of Applied Linguistics, 3(1), 1-24. doi: 10.32601/ejal.461025

Mirzaei, A., \& Es lami, Z. R. (2013). ZPD-activated languaging and collaborative L2 writing. Educational Psychology, 35(1), 5-25. doi: 10.1080/01443410.2013.814198

Moll, L. C. (2013). L. S. Vygotsky and education. London, UK: Oxford University Press.

Mousavi, S. A. (2009). An encyclopedic dictionary of language testing ( $4^{\text {th }}$ edn.). Tehran: Rahnama Press.

Mozaffarzadeh. (2019). Investigating the effectiveness of cloze procedure as a means of activating ZPD through self-assessment of reading comprehension (Unpublished doctoral dissertation). University of Tabriz, Iran.

Ohta, A. S. (2000). Rethinking interaction in SLA: Developmentally appropriate assistance in the zone of proximal development and the acquisition of L2 grammar. In Lantolf, J. (Eds.), Sociocultural theory and second language learning (pp. 51-78). Oxford: Oxford University Press.

Oller, J. W., \& Jonz, J. (1994a). Cloze and coherence. Lewisburg, PA: Bucknell University Press.

O'Toole, J. M., \& King, R. A. (2010). A matter of significance: Can sampling error invalidate cloze estimates of text readability? Language Assessment Quarterly, 7(1), 303-316. doi: $10.1080 / 15434303.2010 .515699$

Perfetti, C. A., \& Stafura, J. (2014). Word knowledge in a theory of reading comprehension. Scientific Studies of Reading, 18(1), 22-37. doi: 10.1080/10888438.2013.827687

Rijk, Y. V., De Mey, L., De Hann, D., Van Oers, B., \& Volman, M. (2017). Reading for meaning: The effect of developmental education on motivation and achievement in reading informative texts in primary school. Research Papers in Education, 32(3), 333-352. doi: $10.1080 / 02671522.2016 .1225789$

Sadeghi, K. (2010). Cloze validation against IELTS reading paper: doubts on correlational validation. Journal of English Teaching and Learning, 2(217), 131-154.

Schumm, J. S. (2006). Reading assessment and instruction for all learners. New York, NY: Guildford Press.

Smagorinsky, P. (2011). Vygotsky's stage theory: The psychology of art and the actor under the direction 
of perezhivanie. Mind, Culture, and Activity, 18(4), 319-341. doi: 10.1080/10749039.2010.518300

Soto-Santiago, S., Rivera, R., \& Mazak, C. M. (2015). Confianza: The emergence of the zone of proximal development in a university ESL course. How Journal, 22(1), 10-25. doi: 10.19183/how.22.1.132

Trace, J., Brown, J. D., Janssen, G., \& Kozhevnikova, L. (2017). Determining cloze item difficulty from item and passage characteristics across different learner backgrounds. Language Testing, 34(2), 151-174. doi: 10.1177/0265532215623581

Unsworth, N., \& McMillan, B. D. (2013). Mind wandering and reading comprehension: Examining the roles of working memory capacity, interest, motivation and topic experience. Journal of Experimental Psychology: Learning, Memory, and Cognition, 39(3), 832-842. doi: 10.1037/a0029669

Van Oers, B. (2009). Developmental education: Improving participation in cultural practices. In M. Fleer, M. Hedegaard, \& J. Tudge (Eds.), Childhood studies and the impact of globalization:
Policies and practices at global and local levels (pp. 213-229). New York: Routledge.

Vygotsky, L. S. (1978). Mind in society: The development of higher psychological processes. Cambridge: Harvard University Press.

Wass, R., \& Golding, C. (2014). Sharpening a tool for teaching: the zone of proximal development. Teaching in Higher Education, 19(6), 671-684. doi: 10.1080/13562517.2014.901958

William, R. S., Ari, O., \& Santamaria, C. N. (2011). Measuring college students' reading comprehension ability using cloze tests. Journal of Research in Reading, 20(3), 215-231. doi: 10.1111/j.1467-9817.2009.01422.x

Yamashita, J. (2003). Process of taking gap-filling test: Comparis on of skilled and less skilled EFL learners. Language Testing, 20(3), 267-293. doi: 10.1191/02655322031t 257oa

Zhang, Y. (2016). The application of schema theory to $E F L$ reading teaching. Paper presented at 2 nd International Conference on Education Technology, Management and Humanities Science on Atlantis Press. doi: 10.2991/etmhs-16.2016.25 